\title{
Pendayagunaan Program Kesetaraan, Pendidikan Nonformal: Kasus Provinsi Sulawesi Barat Tahun 2008/2009
}

\author{
Ida Kintamani Dewi Hermawan \\ e-mail: idakintamani@yahoo.com
}

\begin{abstract}
Abstrak: Tujuan pendayagunaan program kesetaraan, pendidikan nonformal di Provinsi Sulawesi Barat adalah untuk memahami keadaan program kesetaraan di provinsi tersebut yang diukur dengan indikator pemerataan dan mutu pendidikan. Hasil analisis menunjukkan bahwa sesuai dengan standar ideal program kesetaraan di Provinsi Sulawesi Barat dikatakan masih belum merata karena mencapai 36,78\%, belum bermutu dengan nilai capaian sebesar $54,70 \%$, dan keberhasilan program kesetaraan masih rendah dengan nilai capaian sebesar $45,74 \%$. Bila digunakan standar nasional maka kondisi cukup baik. Pemerataan pencapaiannya sebesar $89,74 \%$, mutu sebesar $85,98 \%$, dan keberhasilan program kesetaraan telah mencapai 87,46\%. Disimpulkan bahwa berdasarkan program Kesetaraan di Provinsi Sulawesi Barat diarahkan ke standar ideal maka masih jauh dari harapan karena pencapaiannya kurang dari 50\%. Namun, bila berdasarkan standar nasional sudah cukup baik karena hanya perlu $13,54 \%$ untuk menuntaskan. Disarankan agar pemerintah provinsi yang dalam hal ini adalah Dinas Pendidikan melakukan prioritas dalam pembangunan program kesetaraan di Provinsi Sulawesi Barat, yaitu baik pemerataan maupun mutu pendidikan program kesetaraan harus dibenahi sehingga mendukung program pendidikan dasar dan menengah.
\end{abstract}

Kata kunci: pendayagunaan, pendidikan nonformal, program kesetaraan, pemerataan pendidikan, dan mutu pendidikan

\begin{abstract}
The aim of utilization of equality program, non-formal education in West Sulawesi Province is to understand the existing condition of equality program in West Sulawesi Province that is measured using equity and access to education and quality indicators. The analysis using ideal standard shows that equity program in West Sulawesi Province is still not yet equity with the value of $36.78 \%$, not yet qualify with the value of $54,79 \%$ so that the succesfulness of equity program is still low with the value of $45,74 \%$. When comparing to national standard, equity is $89.74 \%$, quality is $85.98 \%$, and succesful of equity program is $87,46 \%$. So, it is summarized that if equality program in West Sulawesi is compared to ideal standard, it is far away achieve due to less than $50 \%$ but if is used to national standard, it is good enough because it is only $13.54 \%$ to completeness. With this condition, it is suggested that government give a priority to build equality program in West Sulawesi both in equity and quality so that it can support basic and secondary program.
\end{abstract}

Key words: utilization, non-formal education, equality program, equity of education, quality of education, and program performance

\section{Pendahuluan}

\section{Latar Belakang}

Program pendidikan nonformal diarahkan untuk memberikan layanan pendidikan kepada masyarakat yang belum sekolah, tidak pernah sekolah, atau buta aksara, putus sekolah, dan kelompok masyarakat lainnya yang kebutuhannya tidak dapat dipenuhi melalui jalur pendidikan formal. Layanan pendidikan ditujukan kepada semua warga masyarakat baik laki-laki maupun perempuan agar memiliki kemampuan untuk mengembangkan potensi diri dengan penekanan pada penguasaan pengetahuan dan keterampilan vokasional. Dengan demikian, pendidikan nonformal sebagai pengganti, penambah, dan pelengkap pendidikan formal dalam rangka mendukung pendidikan sepanjang hayat. (Departemen Pendidikan Nasional, 2005: 86).

Hasil pendidikan nonformal dapat dihargai setara dengan hasil program pendidikan formal 
yang ditunjukkan melalui Surat Edaran Mendiknas Nomor 107/MPN/MS/2006 tentang Eligibilitas Program Kesetaraan. Hasil ini dilakukan setelah melalui proses penilaian penyetaraan oleh lembaga yang ditunjuk oleh pemerintah atau pemerintah daerah dengan mengacu pada Standar Nasional Pendidikan dan Undang-Undang Nomor 20, Tahun 2003 tentang Sistem Pendidikan Nasional, Pasar 26, Ayat 6). (http://bukhari.or.id).

Berdasarkan pada eligibilitas program kesetaraan maka perlu diketahui bagaimana data dan informasi tentang program kesetaraan yang dapat menunjang pendidikan formal. Pada saat ini data tentang program kesetaraan belum pernah dilakukan analisis baik dari segi banyaknya program yang tersedia di setiap provinsi, kabupaten/kota atau Pusat maupun jumlah peserta didiknya. Data tentang program kesetaraan tersebut masih terpisah-pisah dan tidak ada kaitan satu dengan lainnya sehingga untuk pencarian data tentang program kesetaraan menjadi makin rumit. Kondisi tersebut makin rumit ketika akan dilihat perkembangan data program kesetaraan. Pusat Statistik Pendidikan (PSP) memiliki tugas dan fungsi dalam pendataan pendidikan termasuk pendidikan nonformal juga merasa kesulitan mendapatkan data yang akurat khususnya untuk program kesetaraan. Tugas dan fungsi PSP selain sebagai pusat produksi data pendidikan yang menghasilkan statistik pendidikan maka PSP juga melakukan pendayagunaan/ pelayanan data pendidikan. Dalam melaksanakan pendayagunaan data, PSP perlu mengumpulkan data pendidikan nonformal termasuk program kesetaraan. Pada kenyataannya, mengumpulkan data pendidikan nonformal tidaklah semudah mengumpulkan data pendidikan formal karena pendidikan formal datanya tersedia di setiap sekolah sedangkan pendidikan nonformal datanya terserak di mana-mana karena lokasi pelaksanaan kegiatan belajar dapat berpindah-pindah tempat. Pada pendidikan formal ketika anak akan bersekolah mereka mencari ke sekolah. Sebaliknya, pada pendidikan nonformal peserta didik harus dicari di masyarakat. Kesulitan mencari peserta didik ini menyebabkan data pendidikan nonformal menjadi tidak akurat.

Agar dapat memahami pendidikan nonformal khususnya program kesetaraan maka perlu dilakukan pendayagunaan data program kesetaraan untuk pengambilan keputusan dan penentuan kebijakan pada pendidikan nonformal khusus program kesetaraan. Sebagai contoh pendayagunaan data program kesetaraan maka hanya dipilih salah satu provinsi sehingga dapat dijadikan model untuk pendayagunaan program kesetaraan provinsi lainya. Model ini juga dapat digunakan untuk pendayagunaan program kesetaraan untuk tiap kabupaten/kota dan ketersediaan data yang lengkap.

Berdasarkan uraian tentang latar belakang dirumuskan permasalahan adanya 5 permasalahan, yaitu 1) Bagaimana kondisi pendidikan nonformal di Provinsi Sulawesi Barat?, 2) Bagaimana kondisi program kesetaraan di Provinsi Sulawesi Barat, 3) Bagaimana pendayagunaan indikator pemerataan program kesetaraan di Provinsi Sulawesi Barat, 4) Bagaimana pendayagunaan indikator mutu program kesetaraan di Provinsi Sulawesi Barat, dan 5) Bagaimana keberhasilan program kesetaraan di Provinsi Sulawesi Barat?

Berdasarkan permasalahan tersebut maka tujuan pendayagunaan ini adalah untuk mengetahui data dan informasi mengenai lima variabel, yaitu 1) kondisi pendidikan nonformal di Provinsi Sulawesi Barat, 2) kondisi program kesetaraan di Provinsi Sulawesi Barat, 3) hasil indikator pemerataan program kesetaraan di Provinsi Sulawesi Barat, 4) hasil indikator mutu program kesetaraan di Provinsi Sulawesi Barat, dan 5) keberhasilan program kesetaraan di Provinsi Sulawesi Barat.

\section{Kajian Literatur}

Berikut ini disajikan tentang apa yang dimaksud dengan 1) pendayagunaan data, 2) pendidikan nonformal, 3) program kesetaraan, 4) indikator pemerataan dan perluasan akses pendidikan program kesetaraan, 5) indikator mutu pendidikan program kesetaraan, dan 6) keberhasilan program kesetaraan.

\section{Pendayagunaan Data}

Pendayagunaan data merupakan suatu cara untuk melakukan eksplorasi terhadap hasil produksi data berdasarkan pada perkembangan 
pembangunan pendidikan, kebutuhan pimpinan, atau permintaan data. Pendayagunaan data adalah kegiatan yang bersifat aktif dalam melakukan eksplorasi data. Untuk melakukan eksplorasi dituntut adanya kreativitas dan kepekaan yang tinggi dari para personilnya sehingga dapat selalu memberikan informasi yang relevan kepada pimpinan maupun masyarakat berkenaan dengan pengenalan arah dan permasalahan dunia pendidikan. Untuk dapat mendayagunakan data yang ada diperlukan kemampuan dalam melakukan analisis dan sintesis data maupun interpretasi data. Kemampuan tersebut harus dimiliki oleh semua personil di lingkungan unit kerja yang menangani pendataan. Analisis adalah kemampuan dalam mencari keterkaitan antarvariabel data pendidikan sehingga dapat tercipta informasi-informasi baru yang relevan dengan tujuan pembinaan, penyelenggaraan, dan program pembangunan pendidikan. Sintesis data adalah kemampuan dalam mencari keterkaitan antara variabel data pendidikan dengan data nonpendidikan. (Ida Kintamani, 2007 dan Ida Kintamani, 2009b).

\section{Pendidikan Nonformal}

Berdasarkan Undang-Undang Nomor 20, Tahun 2003 tentang Sistem Pendidikan Nasional Bagian Kelima, Pasal 26 dinyatakan bahwa pendidikan nonformal diselenggarakan bagi warga masyarakat yang memerlukan layanan pendidikan yang berfungsi sebagai pengganti, penambah, dan atau pelengkap pendidikan formal dalam rangka mendukung pendidikan sepanjang hayat. Pendidikan nonformal berfungsi mengembangkan potensi peserta didik dengan penekanan pada penguasaan pengetahuan dan keterampilan fungsional serta pengembangan sikap dan kepribadian profesional. Pendidikan nonformal yang dikembangkan meliputi pendidikan pendidikan anak usia dini (PAUD), pendidikan kesetaraan, pendidikan keaksaraan, peningkatan pembinaan kursus dan pelatihan, pendidikan kecakapan hidup, pendidikan pemberdayaan perempuan, peningkatan budaya baca dan pembinaan perpustakaan. (Departemen Pendidikan Nasional, 2008: 20).

Keberadaan pendidikan nonformal melengkapi keberadaan pendidikan formal untuk mendukung pembelajaran sepanjang hayat. Pendidikan nonformal bersifat luwes bila dibandingkan dengan pendidikan formal. Keluwesan pendidikan nonformal berkenaan dengan waktu belajar, usia peserta didik, isi pelajaran, cara penyelenggaraan pengajaran, dan cara penilaian hasil belajar. Pendidikan nonformal mampu memberikan ruang gerak yang lebih leluasa bagi peserta didik dan pendidik dalam melaksanakan proses belajar mengajar. Dengan sasaran yang sangat besar dan multisegmen, dari usia dini sampai usia lanjut, dari putus sekolah sampai yang berkeinginan meningkatkan pengetahuan dan keterampilan praktis, pendidikan nonformal mampu menerapkan semboyan "melayani yang tak terlayani". (Pusat Statistik Pendidikan, 2008c).

\section{Program Kesetaraan}

Pendidikan kesetaraan adalah jalur pendidikan nonformal dengan standar kompetensi lulusan sama dengan pendidikan formal. Namun, isi, konteks, metodologi, dan pendekatan untuk mencapai standar kompetensi lulusan tersebut berbeda karena perbedaan dalam proses pembelajaran. Sistem pembelajaran pendidikan kesetaraan dirancang agar memiliki kekuatan tersendiri, untuk mengembangkan kecakapan komperehensif dan kompetitif yang berguna dalam peningkatan kemampuan belajar sepanjang hayat.

Pendidikan kesetaraan terdiri dari tiga program, yaitu 2) Paket A setara SD, 2) Paket B setara SMP, dan 3) Paket $C$ setara SMA. Program Paket $A$ dan B dirancang untuk menunjang suksesnya Wajib Belajar Pendidikan Dasar 9 tahun (Wajar Dikdas) dengan prioritas anak usia Wajar Dikdas (7-15 tahun) yang karena berbagai hal tidak bisa mengikuti pendidikan formal. Meskipun demikian, Paket A dan Paket B juga memberi kesempatan bagi orang dewasa yang belum memiliki pendidikan setara Pendidikan Dasar 9 tahun. Program Paket $C$ dirancang untuk mengembankan pendidikan menengah dan memberikan pelayanan pendidikan bagi warga masyarakat yang belum memiliki pendidikan setara SMA. Kurikulum disusun berdasarkan kurikulum SMA jurusan IPS. Bahan belajar disusun dalam bentuk modul sehingga warga belajar 
dapat belajar mandiri. (Pusat Statistik Pendidikan, 2008c).

Pengembangan pendidikan kesetaraan dilakukan melalui pembukaan kelompok-kelompok belajar pada sasaran yang terfokus, yaitu pada daerah yang memiliki APK sangat rendah. Target Paket A adalah siswa putus SD kelas 4 sampai kelas 6. Target Paket B adalah lulusan SD yang tidak melanjutkan dan siswa putus SMP. Target Paket $C$ adalah lulusan SMP yang tidak melanjutkan dan siswa putus SMA.

\section{Indikator Pemerataan dan Perluasan Akses Pendidikan Program Kesetaraan}

Berdasarkan Rencana Strategi Depdiknas tahun 2005-2009 ditetapkan adanya tiga pilar kebijakan pembangunan pendidikan, yaitu 1) pemerataan dan perluasan akses pendidikan, 2) peningkatan mutu, relevansi dan daya saing pendidikan, dan 3) penguatan tata kelola, akuntabilitas, dan citra publik pendidikan. Indikator pendidikan yang ada dalam program pendidikan nonformal juga diarahkan pada tiga pilar kebijakan pembangunan pendidikan. (Departemen Pendidikan nasional, 2005).

Perencanaan pembangunan pendidikan nonformal memerlukan data dan informasi yang terintegrasi, lengkap, dan mutakhir dari berbagai sektor. Integrasi data dan informasi yang komprehensif bisa memungkinkan tercapainya perumusan kebijakan yang tepat dan bermanfaat. Oleh karena itu, diperlukan penjaringan data dan informasi yang mampu menggambarkan keadaan umum daerah beserta data statistik pendidikan nonformal.

Pilar kebijakan pertama, yaitu pemerataan dan perluasan akses pendidikan nonformal menggunakan beberapa indikator kunci. Indikator kunci utama di tingkat nasional untuk mengukur akses pendidikan adalah APK. APK digunakan untuk program PAUD, program kesetaraan, tingkat SMP, SM, dan PT. (Departemen Pendidikan Nasional, 2008). APK adalah perbandingan antara jumlah siswa pada jenjang pendidikan tertentu dengan jumlah penduduk kelompok usia sekolah yang sesuai dan dinyatakan dalam persentase (Ida Kintamani, 2007). Dengan demikian, APK program kesetaraan adalah perbandingan antara jumlah peserta didik program kesetaraan dengan jumlah penduduk kelompok usia yang sesuai dan dikalikan dengan angka 100. Rumus yang digunakan adalah:

\begin{tabular}{|c|c|}
\hline APK Kesetaraan $\quad=$ & \multicolumn{1}{c|}{ Jumlah Peserta Didik } \\
& Jumlah Penduduk Usia Sekolah \\
\hline
\end{tabular}

Catatan : Program Paket A penduduk 7-12 tahun, Paket B penduduk 13-15 tahun, Paket $C$ penduduk 16-18 tahun, dan kesetaraan penduduk 718 tahun.

APK kesetaraan digunakan untuk melihat berapa besar partisipasi program kesetaraan yang bersekolah di jenjang pendidikan dasar dan menengah. Makin tinggi nilai APK berarti makin banyak partisipasi program kesetaraan terhadap pencapaian APK. Sebaliknya, makin kecil nilai APK berarti makin sedikit partisipasi program kesetaraan terhadap pencapaian APK.

Selain indikator kunci yang digunakan di tingkat nasional, terdapat indikator lain yang dapat digunakan untuk mengukur akses pendidikan nonformal program kesetaraan, yaitu 1) rasio peserta didik per kelompok belajar (R-PD/ KB) dan 2) rasio peserta didik per pendidik (R-PD/ $P)$. Untuk mengukur pemerataan pendidikan nonformal program kesetaraan maka digunakan tiga indikator lainnya, yaitu 1) persentase peserta didik menurut jenis kelamin (\%PDJK), 2) perbedaan gender (PG), dan 3) rasio gender (RG). (Pusat Statistik Pendidikan, 2008b).

R-PD/KB dihitung dari pembagian antara peserta didik program kesetaraan dibagi dengan kelompok belajar program kesetaraan. Rumus yang digunakan adalah:

\begin{tabular}{|cc|}
\hline R-PD/KB $=$ & Jumlah Peserta Didik \\
& Jumlah Kelompok Belajar \\
\hline
\end{tabular}

Catatan: Program Paket A, Paket B, Paket C, dan kesetaraan

R-PD/KB untuk melihat kepadatan di setiap kelompok belajar. Makin besar nilai rasio berarti makin padat kelompok belajar. Sebaliknya, makin kecil rasio berarti makin jarang kelompok belajar.

R-PD/P dihitung dari pembagian antara peserta didik program kesetaraan dengan pendidik program kesetaraan. Rumus yang 
digunakan adalah:

\begin{tabular}{|cc|}
\hline R-PD/P $\quad$ Jumlah Peserta Didik \\
& Jumlah Pendidik \\
\hline
\end{tabular}

Catatan: Program Paket A, Paket B, Paket C, dan kesetaraan

R-PD/P untuk melihat seberapa banyak peserta didik dapat dilayani oleh seorang pendidik. Makin kecil nilai rasio berarti pelayanan pendidik terhadap peserta didik makin kecil atau intensif. Sebaliknya, makin besar rasio berarti pelayanan pendidik makin besar atau kurang intensif.

\%PDJK dihitung dari jumlah peserta didik lakilaki suatu program dibagi dengan jumlah peserta didik seluruhnya program yang sesuai atau peserta didik perempuan suatu program dibagi dengan jumlah peserta didik seluruhnya program yang sesuai dan dinyatakan dalam persentase. Rumus yang digunakan ada dua, yaitu:

1) \%PDJKI adalah persentase peserta didik lakilaki

\begin{tabular}{|cc|}
\hline \multirow{2}{*}{$\%$ JPJKI $=$} & Jumlah Peserta Didik Laki2 \\
& Jumlah Peserta Didik seluruhnya \\
\hline
\end{tabular}

2) \%PDJKp adalah persentase peserta didik perempuan

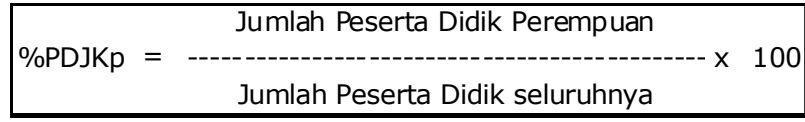

Catatan: Program Paket A, Paket B, Paket C, dan kesetaraan

\%PDJK untuk melihat berapa besar porsi lakilaki atau perempuan terhadap jumlah peserta didik yang bersekolah di program kesetaraan. Makin tinggi porsi laki-laki berarti makin besar peserta didik laki-laki. Sebaliknya, makin rendah porsi lakilaki berarti makin kecil peserta didik laki-laki.

PG dihitung dari persentase peserta didik lakilaki suatu program dikurangi peserta didik perempuan program yang sesuai. Rumus yang digunakan adalah:

\section{PG = \%PDLaki2 - \%PD Perempuan}

Catatan: Program Paket A, Paket B, Paket C, dan kesetaraan
PG kesetaraan digunakan untuk melihat perbedaan partisipasi antara perempuan dan lakilaki sebagai peserta didik. Nilai 0 berarti tidak ada perbedaan gender sedangkan persentase positif berarti terjadi perbedaan gender namun laki-laki lebih besar daripada perempuan sedangkan nilai negatif berarti terjadi perbedaan gender namum perempuan lebih besar daripada laki-laki.

RG dihitung dari persentase peserta didik perempuan suatu program dibagi dengan persentase peserta didik laki-laki program yang sesuai. Rumus yang digunakan adalah:

RG $\quad$ PD Perempuan
\% PD Laki2

Catatan: Program Paket A, Paket B, Paket C, dan kesetaraan

RG digunakan untuk melihat apakah ada keseimbangan antara peserta didik antara perempuan dan laki-laki. Nilai 1 berarti terjadi keseimbangan gender sedangkan nilai kurang dari 1 berarti belum terjadi keseimbangan gender namun perempuan lebih kecil daripada laki-laki sedangkan nilai lebih dari 1 berarti belum terjadi keseimbangan gender namun laki-laki lebih kecil daripada perempuan.

Untuk menentukan bahwa program kesetaraan tersebut sudah merata maka digunakan tiga indikator akses, yaitu APK, R-PD/KB, dan R-PD/P. Selain itu, pengaruh masing-masing indikator berbeda sehingga setiap indikator diberikan bobot berbeda. APK diberi bobot tertinggi yaitu $0,6, \mathrm{R}-$ $\mathrm{PD} / \mathrm{KB}$ dan R-PD/P diberi bobot masing-masing 0,2 sehingga nilai bobot tiga indikator adalah 1 . R$\mathrm{PD} / \mathrm{KB}$ dan $\mathrm{R}-\mathrm{PD} / \mathrm{P}$ dikonversi menjadi persentase dengan cara nilai $\mathrm{R}-\mathrm{PD} / \mathrm{KB}$ dibagi dengan nilai $\mathrm{R}$ $\mathrm{PD} / \mathrm{KB}$ nasional demikian juga R-PD/P dibagi dengan nilai R-PD/P nasional (Pusat Statistik Pendidikan, 2008a). Sebaliknya, indikator pemerataan hanya untuk mengetahui kesenjangan dan ketidakseimbangan gender.

\section{Indikator Mutu Pendidikan Program Kesetaraan}

Sejalan dengan program pemerataan dan perluasan akses pendidikan maka peningkatan mutu untuk semua jenjang pendidikan melalui 
pendidikan formal maupun nonformal juga dilaksanakan. Dianggap bermutu jika memenuhi suatu standar tertentu. Oleh karena itu, peningkatan mutu diarahkan menuju suatu standar tertentu. Peningkatan mutu dapat dilaksanakan pada masukan, keluaran, proses, guru, sarana/prasarana dan biaya yang dikeluarkan untuk pendidikan.

Dalam upaya meningkatkan mutu pendidikan telah dikeluarkan Peraturan Pemerintah RI Nomor 19, Tahun 2005 tentang Standar Nasional Pendidikan yang menjelaskan komponen yang digunakan sebagai standar dalam pengelolaan pendidikan nasional dan menjadi alat ukur akan jaminan mutu pendidikan yang dijalankan oleh program dan/atau satuan penyelenggara pendidikan di tingkat pusat maupun daerah. Standar Nasional Pendidikan (SNP) menurut Undang-Undang Nomor 20, Tahun 2003 Pasal 35 menyatakan, bahwa SNP terdiri atas 8 pokok standar, yaitu standar isi, proses, kompetensi lulusan, pendidik dan tenaga kependidikan, sarana dan prasarana, pengelolaan, pembiayaan, dan penilaian pendidikan yang harus ditingkatkan secara terencana dan berkala. Untuk menilai kelayakan dan mutu pendidikan oleh program PNF, diperlukan instrumen penilaian yang mengukur pemenuhan SNP yang digunakan untuk proses akreditasi suatu progam PNF.

Undang-Undang Nomor 20, Tahun 2003, Pasal 60 menjelaskan, bahwa akreditasi dilakukan untuk menentukan kelayakan program dan satuan pendidikan pada jalur pendidikan formal dan pendidikan nonformal pada setiap jenjang dan jenis pendidikan. (Departemen Pendidikan Nasional, 2003). Akreditasi terhadap program PNF dilakukan oleh pemerintah dan/atau satuan program mandiri yang berwenang sebagai penjamin akuntabilitas publik dan dilakukan atas dasar kriteria yang bersifat terbuka. Akreditasi pada dasarnya merupakan salah satu bentuk penilaian dengan membandingkan apa yang ada dan apa yang dituntut dalam standar yang telah ditetapkan dalam upaya menjaga dan menjamin mutu. Dengan demikian, untuk mengukur tingkat mutu minimal penyelenggaraan program kesetaraan pendidikan nonformal telah dilakukan oleh Badan Akreditasi Nasional Pendidikan Nonformal (BAN PNF) melalui proses akreditasi pada program kesetaraan. Oleh karena itu, BAN PNF dihadapkan pada permasalahan program studi yang harus diakreditasi sedangkan pada saat yang sama BAN PNF harus menjaga kredibilitas proses dan hasil akreditasi. (http:// web.banpnf.or.id/).

Untuk mengukur peningkatan mutu, kajian ini menggunakan beberapa indikator kunci. Indikator kunci utama di tingkat nasional adalah persentase pendidik layak mengajar (\%PL) (Departemen Pendidikan Nasional, 2006). \%PL didefinisikan sebagai perbandingan antara jumlah pendidik yang layak mengajar dikaitkan dengan ijazah yang dimiliki (S1 atau Diploma 4 dan lebih tinggi) suatu program dengan jumlah pendidik seluruhnya pada program yang sesuai dan dinyatakan dalam persentase. Namun, pendidik PNF yang layak mengajar sampai saat ini belum ada ketentuannya. Namun, dalam peningkatan mutu pendidik PNF disesuaikan dengan Undang-Undang Nomor 14, Tahun 2005 tentang Guru dan Dosen yaitu untuk semua jenjang program kesetaraan adalah lulusan S1/Diploma 4 dan lebih tinggi. Rumus yang digunakan adalah:

\begin{tabular}{|l}
\hline PL $\quad=\quad$ Jumlah Pendidik layak mengajar \\
\\
Jumlah Pendidik seluruhnya
\end{tabular}

Catatan: Program Paket A, Paket B, Paket C, dan kesetaraan

Idealnya, \%PL adalah $100 \%$ berarti semua pendidik berusia layak mengajar atau berijazah S1/Diploma 4 dan lebih tinggi.

Selain indikator kunci yang digunakan di tingkat nasional maka terdapat indikator lain untuk mengukur mutu pendidikan dilihat dari sumber daya manusia, peserta didik, dan biaya yang dikeluarkan. Untuk sumber daya manusia ada tiga, yaitu 1) persentase pendidik dengan pekerjaan guru (\%PPG), 2) persentase pendidik yang sudah dilatih (\%PSP), dan 3 ) persentase tingkat pendidikan penyelenggara (\%PS1). Untuk peserta didik ada dua, yaitu 1 ) persentase peserta ujian (\%PU) dan 2) persentase lulusan $(\% \mathrm{~L})$, sedangkan untuk biaya dihitung dari satuan biaya (SB). (Pusat Statistik Pendidikan, 2008a).

Upaya peningkatan mutu dan relevansi program kesetaraan akan dilakukan oleh pemerintah pusat bersama-sama dengan 
pemerintah provinsi dan pemerintah kabupaten/ kota secara terpadu. Penilaian mutu mengacu pada Standar Nasional Pendidikan (SNP) dan pelaksanaan akreditasi dilakukan secara independen oleh BAN PNF.

\%PPG dihitung dari jumlah pendidik suatu program yang bekerja sebagai guru dibagi dengan jumlah pendidik seluruhnya program yang sesuai dan dinyatakan dalam persentase. Rumus yang digunakan adalah:

\begin{tabular}{|c}
\hline PPPG $=$ Jumlah Pendidik dr Guru \\
\\
Jumlah Pendidik seluruhnya
\end{tabular}

Catatan: Program Paket A, Paket B, Paket C, dan kesetaraan

Idealnya, \%PPG adalah $100 \%$ berarti semua pendidik berasal dari guru yang telah memahami bagaimana cara mengajar sehingga dapat meningkatkan mutu program kesetaraan.

\%PSP dihitung dari jumlah pendidik yang sudah dilatih tentang suatu program dibagi dengan jumlah pendidik seluruhnya program yang sesuai dan dinyatakan dalam persentase. Rumus yang digunakan adalah:

\begin{tabular}{|cc|}
\hline \multirow{2}{*}{ JPSP } & Jumlah Pendidik sdh Dilatih \\
& Jumlah Pendidik seluruhnya
\end{tabular}

Catatan : Program Paket A, Paket B, Paket C, dan kesetaraan

Idealnya, \%PSP adalah $100 \%$ berarti semua pendidik sudah mendapatkan pelatihan program kesetaraan yang sesuai sehingga dapat meningkatkan mutu pendidikan kesetaraan.

\%PS1 dihitung dari jumlah penyelenggara yang berpendidikan S1 ke atas suatu program dibagi dengan jumlah penyelenggara seluruhnya program yang sesuai dan dinyatakan dalam persentase. Rumus yang digunakan adalah:

\begin{tabular}{|cc|}
\hline \multirow{2}{*}{$=$} & $\begin{array}{l}\text { Jumlah Penyelenggara S1 ke atas } \\
\text { Jumlah Penyelenggara seluruhnya }\end{array}$ \\
& Jum 100 \\
\hline
\end{tabular}

Catatan : Program Paket A, Paket B, Paket C, dan kesetaraan

Idealnya, \%PS1 adalah 100\% berarti semua penyelenggara sudah memiliki ijazah yang ditentukan sehingga dapat meningkatkan mutu program kesetaraan.
\%PU dihitung dari jumlah peserta ujian suatu program dibagi dengan jumlah peserta didik program yang sesuai dan dinyatakan dalam persentase. Rumus yang digunakan adalah:

\begin{tabular}{|c}
\hline \%PU $=$ Jumlah Peserta Ujian \\
Jumlah Peserta Didik
\end{tabular}

Catatan: Program Paket A, Paket B, Paket C, dan kesetaraan

\%PU makin tinggi makin baik karena makin banyak peserta didik yang mengikuti ujian. Hal ini menunjukkan pentingnya ujian bagi peserta didik untuk meningkatkan mutu peserta didik.

Berdasarkan Keputusan Menteri Pendidikan Nasional RI Nomor 129a/U/2004 tentang Standar Pelayanan Minimal (SPM) bidang pendidikan, 95\% peserta didik yang mengikuti ujian akhir Paket $\mathrm{A}$ dapat lulus ujian sedangkan $80 \%$ peserta didik yang mengikuti ujian akhir Paket B dapat lulus ujian. (Departemen Pendidikan Nasional, 2004). Hal ini berarti semua peserta didik diharapkan dapat mengikuti ujian.

$\%$ dihitung dari jumlah lulusan suatu program dibagi dengan jumlah peserta ujian program yang sesuai dan dinyatakan dalam persentase. Rumus yang digunakan adalah:

\begin{tabular}{c}
\hline $\mathrm{L} \quad=\quad$ Jumlah Lulusan \\
Jumlah Peserta Didik
\end{tabular}

Catatan: Program Paket A, Paket B, Paket C, dan kesetaraan

Idealnya, $\%$ L adalah $100 \%$ berarti semua peserta didik yang mengikuti ujian lulus semuanya.

SB dihitung dari jumlah biaya seluruhnya untuk suatu program dibagi dengan jumlah peserta didik sesuai dengan program tersebut. Rumus yang digunakan adalah:

SB = \begin{tabular}{c|} 
Jumlah biaya \\
Jumlah peserta didik
\end{tabular}

Catatan: Program Paket A, Paket B, Paket C, dan kesetaraan

SB makin tinggi makin baik karena makin banyak biaya yang dikeluarkan untuk penyelenggaraan program Paket.

Untuk menentukan bahwa program kesetaraan tersebut sudah bermutu maka digunakan tujuh indikator mutu. Selain itu, oleh 
karena masing-masing indikator memiliki pengaruh yang berbeda maka setiap indikator diberikan bobot berbeda. Untuk sumber daya manusia diberi bobot 0,5 , peserta didik diberi bobot 0,3 sedangkan biaya diberi bobot 0,2 sehingga jumlah bobot sebesar 1 . Indikator \%PL diberi bobot paling tinggi yaitu $0,3, \%$, \%PPG dan \%PSP masingmasing diberi bobot $0,1, \% \mathrm{PU}$ dan \%L diberi bobot masing-masing sebesar 0,15 sedangkan SB diberi bobot 0,2. SB dikonversi menjadi persentase dengan cara nilai SB dibagi dengan SB nasional. (Pusat Statisik Pendidikan, 2008a).

\section{Keberhasilan Program Kesetaraan}

Keberhasilan program kesetaraan dinyatakan dalam tiga pilar kebijakan program pembangunan pendidikan nonformal. Oleh karena itu, keberhasilan setiap jenjang pendidikan juga akan diukur menggunakan ketiga pilar kebijakan program pembangunan pendidikan yang telah diuraikan sebelumnya. (Ida Kintamani, 2009a). Oleh karena pendayagunaan ini menggunakan dua pilar kebijakan maka kinerja program kesetaraan dinilai dari rata-rata dua pilar kebijakan

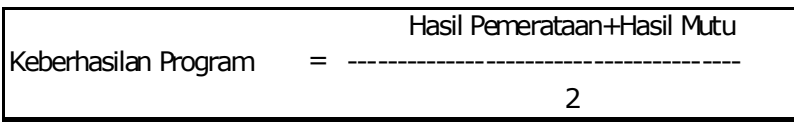

Catatan: Program Paket A, Paket B, Paket C, dan kesetaraan

Keberhasilan program pendidikan kesetaraan dapat digunakan sebagai standar nasional pencapaian sedangkan standar idealnya adalah $100 \%$. Tabel 1 merupakan perhitungan keberhasilan program kesetaraan nasional yang hasilnya dibandingkan dengan ideal sebesar $100 \%$. Untuk itu, keberhasilan nasional dijadikan sebagai standar nasional dan ideal merupakan standar ideal. Pada Tabel 1 ditunjukkan pencapaian nasional, yaitu pemerataan dan perluasan akses pendidikan program kesetaraan sebesar 40,99 sedangkan mutu pendidikan program kesetaraan sebesar 63,62 lebih baik daripada pemerataan sehingga keberhasilan pendidikan program kesetaraan secara nasional sebesar 52,30. Bila digunakan standar ideal sebesar $100 \%$ maka pencapaiannya sedikit lebih besar dari separuhnya. Dengan cara yang sama dapat diketahui keberhasilan program Paket $A$, Paket B, dan Paket C.

Tabel 1. Keberhasilan Program Kesetaraan Nasional Tahun 2008

\begin{tabular}{|l|r|r|r|r|r|r|}
\hline \multirow{2}{*}{ Program } & \multicolumn{2}{|c|}{ Pemeratan } & \multicolumn{2}{c|}{ Mutu } & \multicolumn{2}{c|}{ Keberhasilan } \\
\cline { 2 - 7 } & Nasional & Id eal & Nasional & \multicolumn{1}{c|}{ Ideal } & Nasional & \multicolumn{1}{c|}{ Ideal } \\
\hline Keseta raan & 40.99 & 100.00 & 63.62 & 100.00 & 52.30 & 100.00 \\
\hline Paket A & 40.30 & 100.00 & 51.41 & 100.00 & 45.86 & 100.00 \\
\hline Paket B & 42.24 & 100.00 & 62.88 & 100.00 & 52.56 & 100.00 \\
\hline Paket C & 41.12 & 100.00 & 69.81 & 100.00 & 55.46 & 100.00 \\
\hline
\end{tabular}

program pembangunan pendidikan. Rata-rata tersebut dihitung dari semua nilai "Jumlah" angka semua indikator setelah diberi bobot. Pemilihan kedua kelompok indikator dengan ke-13 jenis nilai indikator ini karena dianggap yang paling tepat mengukur keberhasilan program kesetaraan. (Pusat Statistik Pendidikan, 2008a). Dengan demikian, dapat disimpulkan bahwa keberhasilan program kesetaraan adalah gabungan dari pemerataan dan mutu.

Untuk mengukur keberhasilan program kesetaraan maka hasil indikator pemerataan ditambah dengan hasil indikator mutu kemudian dibagi angka 2. Rumus yang digunakan adalah:

\section{Hasil dan Bahasan}

Untuk melaksanakan pendayagunaan program kesetaraan Provinsi Sulawesi Barat maka digunakan indikator program pembangunan pendidikan nonformal di Provinsi Sulawesi Barat. Untuk itu, akan dijelaskan tentang empat hal yang menjadi tujuan, yaitu 1) kondisi pendidikan nonformal Provinsi Sulawesi Barat; 2) kondisi program kesetaraan Provinsi Sulawesi Barat; 3) hasil indikator pemerataan dan perluasan akses program kesetaraan Provinsi Sulawesi Barat, 4) hasil indikator mutu program kesetaraan Provinsi Sulawesi Barat; dan 5) keberhasilan program kesetaraan Provinsi Sulawesi Barat. 


\section{Kondisi Pendidikan Nonformal Provinsi Sulawesi Barat}

Pendataan Pendidikan Nonformal (PNF) yang dikelola dan dijaring oleh Pusat Statistik Pendidikan atau Depdiknas selama ini terdiri dari tujuh jenis, yaitu 1) Keaksaraan Fungsional (KF), 2) Pendidikan Anak Usia Dini (PAUD), 3) Kesetaraan, 4) Kursus, 5) Kelompok Belajar Usaha $(\mathrm{KBU}), 6)$ Pusat Kegiatan Belajar Masyarakat (PKBM), dan 7) Taman Bacaan Masyarakat (TBM).

Tabel 2 memperlihatkan pada saat ini, Provinsi Sulawesi Barat memiliki program PNF yang lengkap sebanyak tujuh program. Dilihat dari lembaganya maka hanya terdapat lima jenis program, yaitu 104 lembaga PAUD yang terdiri dari 66 Kelompok Bermain (KB), 1 Taman Penitipan Anak (TPA), 3 POS PAUD, dan 34 Satuan PAUD Sejenis (SPS); 12 lembaga kursus, 9 lembaga PKBM, 8 lembaga KBU, dan 11 lembaga TBM. Jenis program PNF yang tidak memiliki lembaga ternyata memiliki kelompok belajar, yaitu sejumlah 448 untuk KF, 599 untuk kesetaraan yang terdiri dari 77 Paket A, 152 Paket B, dan 370 Paket C.

Dilihat dari peserta didik PNF, ternyata peserta didik Kesetaraan adalah yang terbesar (19.271 orang) diikuti PKBM (4.325 orang), KF (2.800 orang), PAUD (2.633 orang) dan yang terkecil adalah pengunjung TBM (104 orang). Dari tujuh jenis program PNF, ternyata yang melaksanakan ujian hanyalah KF, Kesetaraan, kursus dan PKBM dengan jumlah peserta ujian masing-masing adalah 2.800 orang, 21.590 orang, 300 orang, dan 3.625 orang. Peserta yang lulus dari empat program tersebut, masing-masing adalah 2.800 orang, 13.421 orang, 240 orang, dan 3.560 orang. Tujuh jenis program PNF ini dikelola oleh penyelenggara dengan terbesar adalah program kesetaraan (239 orang) dan terkecil adalah program KBU (8 orang). Sejalan dengan itu, jumlah pendidik yang terbesar adalah 1.288 orang dan terkecil adalah program KBU sebesar 24 orang. Dilihat dari dana PNF, yang terbesar terdapat pada program kesetaraan sebesar Rp7.129.690 ribu, sedangkan yang terkecil terdapat di PKBM sebesar Rp90.000 ribu. Selain itu, diketahui juga penduduk usia PAUD adalah sebesar 233.583 orang dan penduduk usia kesetaraan sebesar 307.311 dengan rincian SD (164.952 orang), SMP (64.493 orang), dan SMA (77.886 orang).

\section{Kondisi Pendidikan Program Kesetaraan}

Tabel 3 menunjukkan bahwa jumlah kelompok belajar program kesetaraan di Provinsi Sulawesi Barat sebesar 599 kelompok, terbesar adalah Paket C (370 kelompok) dan terkecil adalah Paket A (77 kelompok). Sebanyak 239 kelompok belajar program kesetaraan ini didanai dari APBN $(39,90 \%)$ dan 360 kelompok berasal dari yayasan $(60,10 \%)$. Jumlah peserta didik seluruhnya adalah

Tabel 2. Gambaran Umum Pendidikan Nonformal, Provinsi Sulawesi Barat Tahun 2008

\begin{tabular}{|c|c|c|c|c|c|c|c|c|c|c|}
\hline No. & Jenis Program & Lembaga & \begin{tabular}{c|}
$\begin{array}{c}\text { Kelompok } \\
\text { Belajar }\end{array}$ \\
\end{tabular} & $\begin{array}{l}\text { Peserta } \\
\text { Didik }\end{array}$ & $\begin{array}{l}\text { Peserta } \\
\text { Ujian }\end{array}$ & Lulusan & $\begin{array}{l}\text { Penye- } \\
\text { lenggara }\end{array}$ & Pendidik & \begin{tabular}{r|} 
Jumlah Dana \\
(Ribuan Rp) \\
\end{tabular} & \begin{tabular}{|c|}
$\begin{array}{c}\text { Penduduk Usia } \\
\text { Sek }\end{array}$ \\
\end{tabular} \\
\hline 1 & Keaksaraan Fungsional & 0 & 448 & 2,800 & 2,800 & 2,800 & 130 & 130 & 982,800 & \\
\hline \multirow[t]{5}{*}{2} & PAUD & 104 & 0 & 2,633 & 0 & 0 & 106 & 215 & 842,000 & 233,583 \\
\hline & a. KB & 66 & 0 & 1,650 & 0 & 0 & 66 & 132 & 300,000 & \\
\hline & b. TPA & 1 & 0 & 85 & 0 & 0 & 3 & 9 & 120,000 & \\
\hline & c. POS PAUD & 3 & 0 & 40 & 0 & 0 & 3 & 6 & 150,000 & \\
\hline & d. SPS & 34 & 0 & 858 & 0 & 0 & 34 & 68 & 272,000 & \\
\hline \multirow[t]{4}{*}{3} & Kesetaraan & 0 & 599 & 19,271 & 21,590 & 13,421 & 239 & 1,288 & $7,129,690$ & 307,331 \\
\hline & a. Paket A Setara SD & 0 & 77 & 1,590 & 1,618 & 658 & 77 & 154 & 752,690 & 164,952 \\
\hline & b. Paket B Setara SMP & 0 & 152 & 5,880 & 8,531 & 5,517 & 152 & 1,064 & $6,025,000$ & 64,493 \\
\hline & c. Paket C Setara SMA & 0 & 370 & 11,801 & 11,441 & 7,246 & 10 & 70 & 352,000 & 77,886 \\
\hline 4 & Kursus & 12 & 0 & 300 & 300 & 240 & 12 & 36 & 264,000 & \\
\hline 5 & PKBM & 9 & 0 & 4,325 & 3,625 & 3,560 & 173 & 519 & 90,000 & \\
\hline 6 & KBU & 8 & 0 & 200 & 0 & 0 & 8 & 24 & 0 & \\
\hline \multirow[t]{2}{*}{7} & TBM & 11 & 0 & 104 & 0 & 0 & 11 & 0 & 185,000 & \\
\hline & Jumlah & 144 & 1,047 & 29,633 & 28,315 & 20,021 & 679 & 2,212 & $9,493,490$ & \\
\hline
\end{tabular}

Catatan : Peserta didik pada TBM adalah pengunjung

Sumber: Kuesioner Profil Pendidikan Nonformal Provinsi Sulawesi Barat, 2008 
19.271 yang terbesar Paket $C$ (11.801 orang), sedangkan yang terkecil Paket A (1.590 orang). Sesuai dengan besarnya peserta didik di Paket $C$ maka latar belakang peserta didik terbesar adalah lainnya sebesar 11.441 orang $(59,37 \%)$. Dilihat dari kelompok usia maka yang terbesar usia $>24$ tahun sebesar 13.769 orang $(71,54 \%)$ sedangkan yang terkecil usia 13-15 tahun sebesar 400 orang $(2,08 \%)$.

Dari 19.271 peserta didik, yang mengikuti ujian lebih banyak sebesar 21.590 orang dirinci 12.212 adalah laki-laki $(56,56 \%)$ dan 9.378 adalah perempuan $(43,44 \%)$. Dengan demikian, dapat dikatakan bahwa laki-laki lebih berminat untuk mendapatkan ijazah sehingga mengikuti ujian daripada perempuan. Namun, dari mereka yang menjadi peserta ujian ternyata hanya 13.421 orang $(62,16 \%)$ yang lulus dengan rincian lulusan laki-laki sebesar 7.920 orang $(59,01 \%)$ juga lebih besar daripada perempuan sebesar 5.501 orang $(40,99 \%)$.

Walaupun jumlah kelompok belajar Paket $\mathrm{C}$ adalah yang terbesar namun jumlah pendidik terbesar ternyata ada Paket B sebesar 1.064 orang $(82,61 \%)$ sedangkan terkecil justru pada Paket C, yaitu sebesar 70 orang $(5,43 \%)$. Tingkat pendidikan pendidik yang terbesar adalah lulusan Diploma sebesar 550 orang $(42,70 \%)$ sedangkan terkecil adalah lulusan SM/MA sebesar 330 orang $(25,62 \%)$. Pekerjaan pendidik terbesar adalah bukan guru sebesar 1.138 orang $(88,35 \%)$. Sebagian besar pendidik tersebut sebesar 916 orang $(71,12 \%)$ diketahui sudah mendapat pelatihan program kesetaraan. Dilihat dari usia, pendidik yang berusia 35-44 tahun adalah kelompok terbesar, sebanyak 819 orang $(63,59 \%)$ dan terkecil pada usia 25-34 tahun sebesar 116 orang $(9,01 \%)$. Masa kerja sebagian besar pendidik $(55,75 \%)$ adalah 2 tahun dan terkecil $(11,72 \%)$ dengan masa kerja 1 tahun.

Dari penyelenggara program kesetaraan sebesar 239 orang, 35,98\% memiliki ijazah Diploma dan terkecil $(31,80 \%)$ adalah lulusan S1 ke atas. Sebagian besar penyelenggara $(95,82 \%)$ belum mendapat pelatihan program kesetaraan sebesar. Dilihat dari sumber dana diketahui sebesar Rp7.129.690 ribu yang kesemuanya bersumber dari APBN. Dana terbesar digunakan untuk proram Paket B sebesar Rp6.025.000 ribu
$(84,51 \%)$ dan terkecil untuk Paket C sebesar Rp352.000,00 (4,94\%).

\section{Paket A}

Jumlah kelompok belajar Paket A di Provinsi Sulawesi Barat adalah 77 kelompok yang kesemuanya dibiayai dari APBN. Peserta didik berjumlah 1.590 orang yang terdiri dari $47,04 \%$ orang laki-laki dan $52,96 \%$ perempuan. Semua peserta didik berasal dari putus SD, berusia 1924 tahun $(39,94 \%)$ dan merupakan kelompok terbesar, diikuti usia $13-15$ tahun $(25,26 \%)$, dan terkecil pada usia $>24$ tahun $(11,32 \%)$. Dari jumlah peserta didik tersebut, sebanyak 1.618 orang menjadi peserta ujian, terdiri dari $56,74 \%$ laki-laki dan $43,26 \%$ perempuan. Berdasarkan mereka yang mengikuti ujian ternyata hanya 658 orang $(40,67 \%)$ yang lulus dengan rincian laki-laki sebesar 420 orang $(63,83 \%)$ lebih besar daripada perempuan sebesar 238 orang $(36,17 \%)$.

Pendidik pada program Paket A adalah 154 orang, dengan rincian 51,95\% laki-laki dan 48,05\% perempuan. Tingkat pendidikan pendidik sebagian besar merupakan lulusan SM/MA (40,91\%) sedangkan sisanya lulusan Diploma dan S1 ke atas $(59,09 \%)$. Pekerjaan pendidik terbesar adalah bukan guru $(67,53 \%)$ dan semua pendidik belum pernah dilatih program Paket A. Kelompok usia terbesar pendidik pada usia 35-44 tahun $(62,99 \%)$ dan terkecil pada usia 44-54 tahun $(15,58 \%)$. Dilihat dari masa kerjanya, dengan terbesar pada masa kerja 2 tahun $(48,70 \%)$, diikuti 1 tahun $(33,77 \%)$ dan sisanya pada masa kerja 3 tahun $(17,53 \%)$.

Penyelenggara program Paket A berjumlah 77 orang, dengan tingkat pendidikan SM/MA yang terbesar $(45,45 \%)$ dan terkecil lulusan Diploma $(25,97 \%)$. Semua penyelenggara belum pernah mendapat pelatihan program Paket $A$. Sumber dana penyelenggaraan program Paket $A$ sebesar Rp752.690 ribu $(10,56 \%)$ yang semuanya dari APBN.

\section{Paket B}

Jumlah kelompok belajar Paket B di Provinsi Sulawesi Barat adalah 152 kelompok yang kesemuanya dibiayai dari APBN. Peserta didik berjumlah 5.880 orang yang terdiri dari $47,99 \%$ orang laki-laki dan $52,01 \%$ perempuan. Semua 
Tabel 3. Gambaran Umum Program Kesetaraan, Provinsi Sulawesi Barat Tahun 2008

\begin{tabular}{|c|c|c|c|c|c|c|c|c|c|}
\hline No. & Variabel & Paket A & $\%$ & Paket B & $\%$ & Paket C & $\%$ & Jum lah & $\%$ \\
\hline \multirow[t]{3}{*}{1} & Kelom pok Belajar & 77 & 100.00 & 152 & 100.00 & 370 & 100.00 & 599 & 100.00 \\
\hline & - APBN & 77 & 100.00 & 152 & 100.00 & 10 & 2.70 & 239 & 39.90 \\
\hline & - Peserta & 0 & 0.00 & 0 & 0.00 & 360 & 97.30 & 360 & 60.10 \\
\hline \multirow[t]{17}{*}{2} & Jum lah Peserta Did ik & & & & & & & & \\
\hline & a. Jenis Kelamin & 1,590 & 100.00 & 5,880 & 100.00 & 11,801 & 100.00 & 19,271 & 100.00 \\
\hline & - Laki-laki & 748 & 47.04 & 2,822 & 47.99 & 6,617 & 56.07 & 10,187 & 52.86 \\
\hline & - Perempuan & 842 & 52.96 & 3,058 & 52.01 & 5,184 & 43.93 & 9,084 & 47.14 \\
\hline & b. Latar Belakang & 1,590 & 8.25 & 5,880 & 30.51 & 11,801 & \multirow{2}{*}{61.24} & 19,271 & 100.00 \\
\hline & - Putus SD & \multirow{3}{*}{ 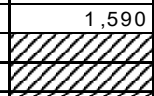 } & \multirow{3}{*}{100.00} & $7 D D D D 7 D=$ & \multirow{2}{*}{ 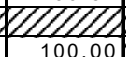 } & \multirow{2}{*}{ BDIIIAAX } & & 1,590 & 8.25 \\
\hline & - Lulus SD & & & 5,880 & & & \multirow{2}{*}{ At } & 5,880 & 30.51 \\
\hline & - Putus SMP & & & & 0.00 & 71771 & & 0 & 0.00 \\
\hline & - Lulus SMP & \multirow{3}{*}{ DEIIIIIII } & \multirow{2}{*}{17117} & \multirow{3}{*}{\multicolumn{2}{|c|}{ 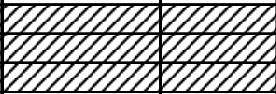 }} & \multicolumn{2}{|r|}{100.00} & 360 & 1.87 \\
\hline & - Putus SMA & & & & & 0 & 0.00 & 0 & 0.00 \\
\hline & - Lainnya & & 989119 & & & 11,441 & 100.00 & 11,441 & 59.37 \\
\hline & c. Kelompok Usia & 1,590 & 100.00 & 5,880 & 100.00 & 11,801 & 100.00 & 19,271 & 100.00 \\
\hline & $\begin{array}{l}-7-12 \text { thn } \\
\end{array}$ & 0 & 0.00 & 7717171711 & DIDIIID & 71717 & 717171 & 0 & 0.00 \\
\hline & $-13-15$ thn & 400 & 25.16 & 0 & 0.00 & 7878 & $17+7$ & 400 & 2.08 \\
\hline & $-16-18$ thn & 375 & 23.58 & 1,745 & 29.68 & 0 & 0.00 & 2,120 & 11.00 \\
\hline & $-19-24$ thn & 635 & 39.94 & 2,200 & 37.41 & 147 & 1.25 & 2,982 & 15.47 \\
\hline & $->24 \operatorname{thn}$ & 180 & 11.32 & 1,935 & 32.91 & 11,654 & 98.75 & 13,769 & 71.45 \\
\hline 3 & Jum lah Peserta Ujian & & & & & & & & \\
\hline & a. Jenis Kelam in & 1,618 & 100.00 & 8,531 & 100.00 & 11,441 & 100.00 & 21,590 & 100.00 \\
\hline & - Laki-laki & 918 & 56.74 & 4,900 & 57.44 & 6,394 & 55.89 & 12,212 & 56.56 \\
\hline & - Perempuan & 700 & 43.26 & 3,631 & 42.56 & 5,047 & 44.11 & 9,378 & 43.44 \\
\hline 4 & Jum lah Lulusan & & & & & & & & \\
\hline & a. Jenis Kelamin & 658 & 100.00 & 5,517 & 100.00 & 7,246 & 100.00 & 13,421 & 100.00 \\
\hline & - Laki-laki & 420 & 63.83 & 3,500 & 63.44 & 4,000 & 55.20 & 7,920 & 59.01 \\
\hline & - Perempuan & 238 & 36.17 & 2,017 & 36.56 & 3,246 & 44.80 & 5,501 & 40.99 \\
\hline 5 & Jum lah Pendidik & & & & & & & & \\
\hline & a. Jenis Kelam in & 154 & 100.00 & 1,064 & 100.00 & 70 & 100.00 & 1,288 & 100.00 \\
\hline & - Laki-laki & 80 & 51.95 & 600 & 56.39 & 40 & 57.14 & 720 & 55.90 \\
\hline & - Perempuan & 74 & 48.05 & 464 & 43.61 & 30 & 42.86 & 568 & 44.10 \\
\hline & b. Pendidikan & 154 & 100.00 & 1,064 & 100.00 & 70 & 100.00 & 1,288 & 100.00 \\
\hline & $-\mathrm{SM} / \mathrm{MA}$ & 63 & 40.91 & 267 & 25.09 & 0 & 0.00 & 330 & 25.62 \\
\hline & - Dip loma & 45 & 29.22 & 485 & 45.58 & 20 & 28.57 & 550 & 42.70 \\
\hline & $-\mathrm{S} 1 / \mathrm{S} 2 / \mathrm{S} 3$ & 46 & 29.87 & 312 & 29.32 & 50 & 71.43 & 408 & 31.68 \\
\hline & c. Pekerjaan & 154 & 100.00 & 1,064 & 100.00 & 70 & 100.00 & 1,288 & 100.00 \\
\hline & - Guru & 50 & 32.47 & 100 & 9.40 & 0 & 0.00 & 150 & 11.65 \\
\hline & - Bukan Guru & 104 & 67.53 & 964 & 90.60 & 70 & 100.00 & 1,138 & 88.35 \\
\hline & d. Pela tih an & 154 & 100.00 & 1,064 & 100.00 & 70 & 100.00 & 1,288 & 100.00 \\
\hline & - Sudah dilatih & 0 & 0.00 & 916 & 86.09 & 0 & 0.00 & 916 & 71.12 \\
\hline & - Belum dilatih & 154 & 100.00 & 148 & 13.91 & 70 & 100.00 & 372 & 28.88 \\
\hline & e.Kelompok Usia & 154 & 100.00 & 1,064 & 100.00 & 70 & 100.00 & 1,288 & 100.00 \\
\hline & $-25-34$ th & 33 & 21.43 & 76 & 7.14 & 7 & 10.00 & 116 & 9.01 \\
\hline & $-35-44$ th & 97 & 62.99 & 673 & 63.25 & 49 & 70.00 & 819 & 63.59 \\
\hline & $-45-54$ th & 24 & 15.58 & 315 & 29.61 & 14 & 20.00 & 353 & 27.41 \\
\hline & f. Masa Kerja & 154 & 11.96 & 1,064 & 82.61 & 70 & 5.43 & 1,288 & 100.00 \\
\hline & -1 th & 52 & 33.77 & 88 & 8.27 & 11 & 15.71 & 151 & 11.72 \\
\hline & $-2 \mathrm{th}$ & 75 & 48.70 & 607 & 57.05 & 36 & 51.43 & 718 & 55.75 \\
\hline & $-3 \mathrm{th}$ & 27 & 17.53 & 369 & 34.68 & 23 & 32.86 & 419 & 32.53 \\
\hline 6 & Penyelenggara & & & & & & & & \\
\hline & a. Pendidikan & 77 & 100.00 & 152 & 100.00 & 10 & 100.00 & 239 & 100.00 \\
\hline & $-S M / M A$ & 35 & 45.45 & 42 & 27.63 & 0 & 0.00 & 77 & 32.22 \\
\hline & - Dip loma & 20 & 25.97 & 63 & \begin{tabular}{l|l}
41.45 \\
\end{tabular} & 3 & 30.00 & 86 & 35.98 \\
\hline & $-\mathrm{S} 1 / \mathrm{S} 2 / \mathrm{S} 3$ & 22 & 28.57 & 47 & \begin{tabular}{l|l|}
30.92 \\
\end{tabular} & 7 & 70.00 & 76 & 31.80 \\
\hline & b. Pela tih an & 77 & 100.00 & 152 & 100.00 & 10 & 100.00 & 239 & 100.00 \\
\hline & - Sudah dilatih & 0 & 0.00 & 10 & 6.58 & 0 & 0.00 & 10 & 4.18 \\
\hline & - Belum dilatih & 77 & 100.00 & 142 & 93.42 & 10 & 100.00 & 229 & 95.82 \\
\hline 7 & Jumlah Dana & 752,690 & 10.56 & $6,025,000$ & 84.51 & 352,000 & 4.94 & $7,129,690$ & 100.00 \\
\hline
\end{tabular}

Sumber: Kuesioner Profil Pendidikan Nonformal Provinsi Sulawesi Barat, 2008.

peserta didik berasal dari lulusan SD, berusia 1924 tahun $(37,41 \%)$ dan merupakan kelompok terbesar, diikuti usia $>24$ tahun $(32,91 \%)$, dan terkecil pada usia $16-18$ tahun $(29,68 \%)$. Dari jumlah peserta didik tersebut, sebanyak 8.531 orang menjadi peserta ujian, terdiri dari $57,44 \%$ laki-laki dan $42,56 \%$ perempuan. Berdasarkan mereka yang mengikuti ujian ternyata hanya
5.517 orang $(64,67 \%)$ yang lulus dengan rincian laki-laki sebesar 3.500 orang $(63,44 \%)$ lebih besar daripada perempuan sebesar 2.017 orang $(36,56 \%)$.

Pendidik pada program Paket B adalah 1.064 orang, dengan rincian 58,39\% laki-laki dan 43,61\% perempuan. Tingkat pendidikan pendidik sebagian besar merupakan Iulusan Diploma 45,58\% 
sedangkan sisanya lulusan SM dan S1 ke atas $(54,42 \%)$. Pekerjaan pendidik terbesar adalah bukan guru sebesar $90,60 \%$ dan sebagian besar $(86,09 \%)$ pendidik belum pernah dilatih program Paket B. Kelompok usia terbesar pendidik pada usia 35-44 tahun $(63,25 \%)$ dan terkecil pada usia 25-34 tahun (7,14\%). Dilihat dari masa kerjanya, dengan terbesar pada masa kerja 2 tahun $(57,05 \%)$, diikuti 3 tahun $(34,68 \%)$ dan sisanya pada masa kerja 1 tahun $(8,27 \%)$.

Penyelenggara program Paket B berjumlah 152 orang, dengan tingkat pendidikan Diploma yang terbesar $(41,45 \%)$ dan terkecil lulusan SM/ MA $(27,63 \%)$. Sebagian besar $(93,42 \%)$ penyelenggara belum pernah mendapat pelatihan program Paket B. Sumber dana penyelenggaraan program Paket B sebesar Rp6.025.000 ribu $(84,51 \%)$ yang semuanya dari APBN.

\section{Paket C}

Jumlah kelompok belajar Paket $C$ di Provinsi Sulawesi Barat adalah 370 kelompok yang sebagian besar $(97,30 \%)$ dibiayai dari peserta dan sisanya $(2,70 \%)$ dari APBN. Peserta didik berjumlah 11.801 orang yang terdiri dari $56,07 \%$ orang laki-laki dan $43,93 \%$ perempuan. Sebagian besar $(96,95 \%)$ peserta didik berasal dari lainnya, berusia $>24$ tahun $(98,75 \%)$ dan merupakan kelompok terbesar dan usia 19-24 tahun (1,25\%). Dari jumlah peserta didik tersebut, sebanyak 11.441 orang $(96,95 \%)$ menjadi peserta ujian, terdiri dari 55,89\% laki-laki dan 44,11\% perempuan. Berdasarkan mereka yang mengikuti ujian ternyata hanya 7.246 orang $(63,33 \%)$ yang lulus dengan rincian laki-laki sebesar 4.000 orang $(55,20 \%)$ lebih besar daripada perempuan sebesar 3.246 orang $(44,80 \%)$.

Pendidik pada program Paket C adalah 70 orang, dengan rincian $57,14 \%$ laki-laki dan $42,86 \%$ perempuan. Tingkat pendidikan pendidik sebagian besar merupakan lulusan S1 ke atas $(71,43 \%)$ sedangkan sisanya lulusan Diploma $(28,57 \%)$. Pekerjaan pendidik kesemuanya bukan guru dan belum pernah dilatih program Paket C. Kelompok usia terbesar pendidik pada usia 35-44 tahun $(70,00 \%)$ dan terkecil pada usia 25-34 tahun $(10,00 \%)$. Dilihat dari masa kerjanya, dengan terbesar pada masa kerja 2 tahun $(51,43 \%)$, diikuti 3 tahun $(32,86 \%)$ dan sisanya pada masa kerja 1 tahun $(15,71 \%)$.

Penyelenggara program Paket $\mathrm{C}$ berjumlah 10 orang, dengan tingkat pendidikan S1 ke atas yang terbesar $(70,00 \%)$ dan terkecil lulusan Diploma $(30,00 \%)$. Semua penyelenggara belum pernah mendapat pelatihan program Paket C. Sumber dana penyelenggaraan program Paket $C$ sebesar Rp352.000 ribu (4,94\%) yang semuanya dari APBN.

\section{Hasil Indikator Program Kesetaraan}

Berdasarkan Tabel 4, akses pendidikan program kesetaraan Provinsi Sulawesi Barat yang ditunjukkan melalui APK sebesar 6,27\%. Hal ini berarti program kesetaraan hanya menyumbang $6,27 \%$ pada jenjang pendidikan dasar dan menengah. Untuk program Paket A sebesar 0,96\% sangat kecil jika dibandingkan dengan Paket $B$ sebesar 9,12\% dan Paket $C$ sebesar $15,15 \%$. Indikator R-PD/KB program kesetaraan sebesar 32 dan terkecil adalah Paket A sebesar 21 dan terbesar Paket B sebesar 39 sedangkan Paket C sebesar 32. Indikator R-PD/P program kesetaraan sebesar 15 dan terkecil adalah Paket B sebesar 6 dan terbesar Paket $C$ sebesar 169 sedangkan Paket A sebesar 10.

Pemerataan pendidikan program kesetaraan Provinsi Sulawesi Barat ditunjukkan dari indikator $\%$ PDJK di mana laki-laki sebesar 52,86\% lebih

Tabel 4. Indikator Pemerataan Program Kesetaraan, Provinsi Sulawesi Barat Tahun 2008

\begin{tabular}{|l|r|r|r|r|r|r|r||}
\hline \multirow{2}{*}{ Program } & \multicolumn{3}{|c|}{ Akses Pendidikan } & \multicolumn{4}{c|}{ Pemerataan Pendidikan } \\
\cline { 2 - 9 } & APK & R-PD/KB & R-PD/P & \%PDJKI & \%PDKLp & PG & \multicolumn{1}{c|}{ RG } \\
\hline Kesetaraan & 6.27 & 32.17 & 14.96 & 52.86 & 47.14 & 5.72 & 0.89 \\
\hline Paket A & 0.96 & 20.65 & 10.32 & 47.04 & 52.96 & -5.91 & 1.13 \\
\hline Paket B & 9.12 & 38.68 & 5.53 & 47.99 & 52.01 & -4.01 & 1.08 \\
\hline Paket C & 15.15 & 31.89 & 168.59 & 56.07 & 43.93 & 12.14 & 0.78 \\
\hline
\end{tabular}


besar daripada perempuan sebesar $47,14 \%$. Hal ini menunjukkan terjadi perbedaan gender sebesar $5,72 \%$ dan ketidakseimbangan gender dengan rasio gender sebesar 0,89 . Hal ini berarti partisipasi peserta didik program kesetaraan belum seimbang antara laki-laki dan perempuan karena nilainya tidak sama dengan 1 dan laki-laki lebih baik partisipasinya daripada perempuan. (Pusat Statistik Pendidikan, 2008b). Kondisi pemerataan pendidikan pada Paket B adalah yang terbaik karena memiliki PG terkecil sebesar $4,01 \%$. Berarti peserta didik perempuan lebih besar daripada laki-laki dengan RG sebesar 1,08. Namun belum terjadi keseimbangan gender karena jauh dari 1 . Paket $\mathrm{C}$ yang terburuk karena memiliki PG terbesar sebesar $12,14 \%$ yang berarti laki-laki lebih besar daripada perempuan dengan RG sebesar 0,78 sangat jauh dari seimbang yang seharusnya sebesar 1 . Paket A memiliki PG sebesar $-5,91 \%$ yang berarti perempuan lebih besar daripada laki-laki dengan RG sebesar 1,13 masih jauh dari seimbang yang seharusnya sebesar 1.

Berdasarkan Tabel 5 maka indikator \%PL program kesetaraan menunjukkan pendidik yang layak mengajar di Provinsi Sulawesi Barat ádalah sebesar $31,68 \%$. Pendidik terbesar adalah pendidik di Paket $C(71,43 \%)$ dan terkecil adalah pendidik Paket B $(29,32 \%)$ sedangkan Paket A sebesar $29,87 \%$. Indikator \%PTG yaitu pendidik program kesetaraan yang berasal dari guru diketahui sebesar $11,65 \%$. Pendidik terbesar dari pendidik Paket A $(32,47 \%)$ dan Paket B $(9,40 \%)$ sedangkan pendidik Paket $\mathrm{C}$ tak ada yang berasal dari guru. Indikator \%PSP atau pendidik program kesetaraan yang telah mendapatkan pelatihan program kesetaraan adalah sebesar $71,12 \%$. Namun, pendidik Paket A dan Paket C sama sekali belum mendapatkan pelatihan, sedangkan Paket $B$ yang memperoleh pendidikan ádalah sebesar $86,09 \%$.
Indikator \%PL atau penyelenggara program kesetaraan yang berijazah S1 dan lebih tinggi ádalah sebesar $64,02 \%$. \%PL terbesar adalah penyelenggara Paket A $(74,03 \%)$ dan terkecil tutor Paket B $(58,55 \%)$ sedangkan Paket C $(70,00 \%)$. Dilihat dari peserta didik maka indikator \%PU program kesetaraan yang menunjukkan besarnya peserta didik yang menjadi peserta ujian sebesar $112,03 \%$ yang berarti lebih besar dari peserta didik di program kesetaraan. Ternyata pada Paket A dan Paket B, indikator \%PU sudah lebih besar dari $100 \%$ sedangkan Paket $C$ lebih rendah sebesar $96,95 \%$. Indikator $\% \mathrm{~L}$ program kesetaraan yang menunjukkan besarnya lulusan mencapai $62,16 \%$ terbesar adalah lulusan Paket B $(64,67 \%)$ dan terkecil adalah Paket A $(40,67 \%)$ sedangkan Paket $C$ sebesar 63,33\%. Dilihat dari biaya maka SB program kesetaraan adalah sebesar Rp369.970,00, SB Paket B yang terbesar (Rp1.024.660,00) dan terkecil adalah Paket $C$ (Rp29.828,00), sedangkan Paket $A$ adalah sebesar Rp463.390,00.

\section{Keberhasilan Program Kesetaraan}

Indikator pemerataan dan perluasan akses pendidikan digunakan untuk menilai pemerataan pendidikan program kesetaraan yang dapat dicapai, indikator mutu digunakan untuk menilai mutu pendidikan program kesetaraan yang dapat dicapai. Gabungan dari kedua indikator tersebut digunakan untuk menilai keberhasilan program pembangunan pendidikan khusus program kesetaraan.

Indikator yang diambil untuk menghitung pemerataan hanya tiga jenis, yaitu APK, R-PD/KB, dan R-PD/P sedangkan indikator untuk menghitung mutu ada tujuh jenis, yaitu \% $\mathrm{PL}$, $\%$ PPG, \%PSP, \%PS1, \%PU, \%L, dan SB. Oleh karena indikator pemerataan dan mutu dalam bentuk persentase dan rasio maka indikator

Tabel 5. Indikator Mutu Program Kesetaraan, Provinsi Sulawesi Barat Tahun 2008

\begin{tabular}{|l|r|r|r|r|r|r|r|}
\hline Program & \multicolumn{1}{|c|}{ \%PL } & \multicolumn{1}{|c|}{ \%PPG } & \multicolumn{1}{c|}{ \%PSP } & \%PS1 & \multicolumn{1}{c|}{ \%PU } & \%L & \multicolumn{1}{c|}{ SB } \\
\hline Kesetaraan & 31.68 & 11.65 & 71.12 & 64.02 & 112.03 & 62.16 & 369,970 \\
\hline Paket A & 29.87 & 32.47 & 0.00 & 74.03 & 101.76 & 40.67 & 473,390 \\
\hline Paket B & 29.32 & 9.40 & 86.09 & 58.55 & 145.09 & 64.67 & $1,024,660$ \\
\hline Paket C & 71.43 & 0.00 & 0.00 & 70.00 & 96.95 & 63.33 & 29,828 \\
\hline
\end{tabular}


dalam bentuk rasio dikonversi dalam bentuk persentase. Untuk jelasnya, terdapat tiga indikator yang harus mengalami konversi, yaitu $\mathrm{R}-\mathrm{PD} / \mathrm{KB}, \mathrm{R}-\mathrm{PD} / \mathrm{P}$ dan SB. Dalam menentukan konversi maka digunakan nilai nasional sehingga nilai yang kurang dari nasional menghasilkan nilai kurang dari $100 \%$, sebaliknya yang lebih dari nilai nasional dinyatakan > 100\%.

Nilai pendidikan merata merupakan penjumlahan dari tiga jenis indikator pemerataan setelah konversi dan diberikan bobot. Nilai pendidikan bermutu adalah penjumlahan dari tujuh indikator mutu setelah diberikan bobot. Nilai keberhasilan program kesetaraan adalah penjumlahan nilai pendidikan merata dan pendidikan bermutu kemudian dibagi 2 . Nilai maksimal untuk masing-masing indikator dan keberhasilan program kesetaraan adalah 100.

Tabel 6 menunjukkan pemerataan program kesetaraan setelah dilakukan konversi dan diberikan bobot sehingga nilainya menjadi 36,78 dengan rincian tertinggi adalah Paket $\mathrm{B}$ sebesar 50,53 dan terkecil adalah Paket $C$ sebesar 38,06 sedangkan Paket A sebesar 38,14. Jika digunakan standar ideal maka pemerataan program kesetaraan mencapai $36,78 \%$ masih jauh dari $100 \%$ jika dibandingkan dengan standar nasional $(40,99)$ diketahui telah mencapai $89,74 \%$ sehingga hanya $10,26 \%$ yang perlu dituntaskan pemerataannya.
Untuk Paket A dengan menggunakan standar ideal, diketahui bahwa pemerataan Paket $A$ adalah sebesar 38,14\%, jika digunakan standar nasional maka pemerataan Paket A mencapai $94,64 \%$ sehingga hanya $5,36 \%$ perlu dituntaskan pemerataannya. Untuk Paket B dengan menggunakan standar ideal, pemerataan Paket $B$ adalah sebesar 50,53\% jika digunakan standar nasional maka pemerataan Paket B mencapai $119,63 \%$ lebih baik dari nasional. Oleh karena itu, Paket B harus diarahkan menuju standar ideal. Untuk Paket $C$ dengan menggunakan standar ideal, pemerataan Paket $\mathrm{C}$ adalah sebesar $38,06 \%$ jika digunakan standar nasional maka pemerataan Paket $C$ adalah sebesar $92,57 \%$ sehingga hanya $7,43 \%$ yang perlu dituntaskan pemerataannya.

Tabel 7 menunjukkan mutu program kesetaraan setelah dilakukan konversi dan diberikan bobot sehingga nilainya menjadi 54,70 dengan rincian tertinggi adalah Paket B sebesar 73,23 dan terkecil adalah Paket $C$ sebesar 45,83 sedangkan Paket A sebesar 56,92. Bila digunakan standar ideal maka mutu program kesetaraan mencapai $36,78 \%$ masih jauh dari $100 \%$ sedangkan jika dibandingkan dengan standar nasional $(63,62)$ mencapai $85,98 \%$ sehingga hanya $14,02 \%$ yang perlu dituntaskan mutunya.

Untuk program Paket A dengan menggunakan standar ideal, mutu Paket A adalah sebesar

Tabel 6. Pemerataan Program Kesetaraan, Provinsi Sulawesi Barat Tahun 2008

\begin{tabular}{|l|r|r|r|r|r|r|r|r||}
\hline Program & \multicolumn{1}{|c|}{ APK } & \multicolumn{2}{|c|}{ R-PD/KB } & \multicolumn{2}{|c|}{ R-PD/P } & Jumlah & Nasional & \multicolumn{1}{c|}{$\%$} \\
\hline Bobot & 0.6 & \multicolumn{1}{|c|}{ Konversi } & 0.2 & Konversi & 0.2 & 1 & & \\
\hline Kesetaraan & 3.76 & 128.90 & 25.78 & 36.20 & 7.24 & 36.78 & 40.99 & 89.74 \\
\hline Paket A & 0.58 & 96.76 & 19.35 & 91.06 & 18.21 & 38.14 & 40.30 & 94.64 \\
\hline Paket B & 5.47 & 139.55 & 27.91 & 85.78 & 17.16 & 50.53 & 42.24 & 119.63 \\
\hline Paket C & 9.09 & 141.46 & 28.29 & 3.39 & 0.68 & 38.06 & 41.12 & 92.57 \\
\hline \hline
\end{tabular}

Tabel 7. Mutu Program Kesetaraan, Provinsi Sulawesi Barat Tahun 2008

\begin{tabular}{|l|r|r|r|r|r|r|r|r|r|r|r|}
\hline Program & \multicolumn{1}{c|}{ \%PL } & \multicolumn{1}{c|}{ \%PPG } & \multicolumn{1}{c|}{ \%PSP } & \multicolumn{1}{c|}{ \%PS1 } & \multicolumn{1}{c|}{ \%PU } & \multicolumn{1}{c|}{ \% } & \multicolumn{2}{|c|}{ SB } & Jumlah & Nasional & \% \\
\hline Bobot & 0.2 & 0.1 & 0.1 & 0.1 & 0.15 & 0.15 & Konversi & 0.2 & & & \\
\hline Kesetaraan & 6.34 & 1.16 & 7.11 & 6.40 & 16.81 & 9.32 & 37.81 & 7.56 & 54.70 & 63.62 & 85.98 \\
\hline Paket A & 5.97 & 3.25 & 0.00 & 7.40 & 15.26 & 6.10 & 94.68 & 18.94 & 56.92 & 51.41 & 110.72 \\
\hline Paket B & 5.86 & 0.94 & 8.61 & 5.86 & 21.76 & 9.70 & 10247 & 20.49 & 73.23 & 6288 & 116.45 \\
\hline Paket C & 14.29 & 0.00 & 0.00 & 7.00 & 14.54 & 9.50 & 249 & 0.50 & 45.83 & 69.81 & 65.65 \\
\hline
\end{tabular}


$56,92 \%$, sedangkan dengan standar nasional $(51,41)$ maka mutu Paket A sebesar $110,72 \%$ lebih baik dari nasional. Oleh karena itu, Paket $A$ harus diarahkan menuju standar ideal. Sama dengan Paket $A$, untuk Paket $B$ dan digunakan standar ideal, mutu Paket B sebesar $73,23 \%$ sedangkan jika digunakan standar nasional $(62,88)$ maka mutu Paket B sebesar $116,45 \%$ lebih baik dari nasional. Oleh karena itu, Paket B juga harus diarahkan menuju standar ideal. Untuk Paket $\mathrm{C}$ dan digunakan standar ideal, mutu Paket C sebesar $45,83 \%$ sedangkan jika digunakan standar nasional $(69,81)$ maka mutu Paket C sebesar $65,65 \%$ sehingga masih sebesar $34,35 \%$ yang perlu dituntaskan mutunya.
Sulawesi Barat tahun 2008 perlu dipahami terlebih keadaan pendidikan nonformal, keadaan pendidikan program kesetaraan dengan menggunakan dua pilar kebijakan, yaitu indikator pemerataan dan perluasan akses pendidikan dan indikator mutu pendidikan. Berdasarkan kedua indikator tersebut maka dapat dihitung keberhasilan program kesetaraan di Provinsi Sulawesi Barat.

Provinsi Sulawesi Barat memiliki ketujuh program pendidikan nonformal dan yang terbesar adalah program kesetaraan. Program kesetaraan disebut terbesar karena semua variabel pendidikan nonformal, yaitu kelompok belajar, peserta didik, peserta ujian, lulusan, penyeleng-

Tabel 8. Keberhasilan Program Kesetaraan, Provinsi Sulawesi Barat Tahun 2008

\begin{tabular}{|l|r|r|r|r|r|r|r|r|r|}
\hline \multirow{2}{*}{ Program } & \multicolumn{3}{|c|}{ Pemerataan } & \multicolumn{3}{c|}{ Mutu } & \multicolumn{3}{c|}{ Keberhasilan } \\
\cline { 2 - 10 } & \multicolumn{1}{|c|}{ Sulbar } & Nasional & \multicolumn{1}{c|}{$\%$} & \multicolumn{1}{c|}{ Sulbar } & Nasional & \multicolumn{1}{c|}{$\%$} & \multicolumn{1}{c|}{ Sulbar } & \multicolumn{1}{c|}{ Nasional } & $\%$ \\
\hline Kesetaraan & 36.78 & 40.99 & 89.74 & 54.70 & 63.62 & 85.98 & 45.74 & 52.30 & 87.46 \\
\hline Paket A & 38.14 & 40.30 & 94.64 & 56.92 & 51.41 & 110.72 & 47.53 & 45.86 & 103.65 \\
\hline Paket B & 50.53 & 42.24 & 119.63 & 73.23 & 62.88 & 116.45 & 61.88 & 52.56 & 117.72 \\
\hline Paket C & 38.06 & 41.12 & 92.57 & 45.83 & 69.81 & 65.65 & 41.94 & 55.46 & 75.62 \\
\hline
\end{tabular}

Tabel 8 menunjukkan keberhasilan program kesetaraan di Provinsi Sulawesi Selatan yang dihitung dari nilai pemerataan dan nilai mutu. Nilai pemerataan berdasarkan tiga jenis indikator tersebut sebesar 36,78 sedangkan nilai mutu berdasarkan tujuh jenis indikator sebesar 54,70 sehingga keberhasilan program mencapai 45,74. Dengan menggunakan standar ideal sebesar $100 \%$, keberhasilan program kesetaraan yang diperoleh sebesar $45,74 \%$ sehingga masih ada $54,25 \%$ yang perlu dituntaskan sedangkan dengan menggunakan standar nasional $(52,30)$ maka keberhasilan program kesetaraan sebesar $87,46 \%$ sehingga hanya ada $12,54 \%$ yang harus dituntaskan keberhasilannya.

Bila dirinci menurut jenis program kesetaraan maka keberhasilan program Paket A sebesar 47,53. Dengan menggunakan standar ideal maka keberhasilan program Paket A hanya mencapai $47,53 \%$ namun bila digunakan standar nasional $(45,86)$ maka keberhasilan program Paket $A$ sudah lebih baik daripada nasional dengan nilai 103,65\%. Dengan demikian, untuk program Paket A supaya diarahkan pada standar ideal. Keberhasilan program Paket $\mathrm{B}$ dan berdasarkan standar ideal sebesar 61,88 yang paling baik jika dibandingkan dengan program kesetaraan lainnya. Hal ini berarti keberhasilan program Paket B telah mencapai $61,88 \%$ namun bila digunakan standar nasional $(52,56)$ maka keberhasilan program Paket B sudah lebih baik daripada nasional dengan nilai $117,72 \%$. Dengan demikian, untuk program Paket B supaya diarahkan pada standar ideal. Keberhasilan program Paket $C$ dan berdasarkan standar ideal sebesar 41,94 yang paling buruk jika dibandingkan dengan program kesetaraan lainnya. Hal ini berarti keberhasilan program Paket C mencapai $41,94 \%$ namun bila digunakan standar nasional $(55,46)$ maka keberhasilan program Paket $\mathrm{C}$ lebih buruk daripada nasional dengan nilai $75,62 \%$. Dengan demikian, masih harus dituntaskan sebesar $24,38 \%$ agar program kesetaraan berhasil.

\section{Simpulan dan Saran}

\section{Simpulan}

Berdasarkan hasil dan bahasan maka dapat disimpulkan bahwa untuk melakukan pendayagunaan terhadap program kesetaraan Provinsi 
gara, pendidik, dan biaya yang digunakan paling besar jika dibandingkan dengan program pendidikan nonformal lainnya. Program kesetaraan ini banyak dikelola oleh peserta atau masyarakat sendiri $(60,10 \%)$ dengan peserta didik sebesar 19.271 orang, pendidik sebesar 1.288 orang, penyelenggara sebesar 239 orang, dan dana sebesar Rp7.129.690 ribu.

Berdasarkan standar ideal, pemerataan program kesetaraan Provinsi Sulawesi Barat mencapai $36,78 \%$ sehingga masih $63,22 \%$ yang harus ditangani sehingga tuntas. Namun, bila digunakan standar nasional maka pemerataan telah tercapai $89,74 \%$ sehingga yang harus dituntaskan hanya 10,26\%.

Berdasarkan standar ideal, mutu pendidikan tinggi di Provinsi Sulawesi Barat ternyata masih menjadi masalah pokok dalam program pembangunan pendidikan. Kondisi ini nampak dari hasil pendayagunaan hanya sebesar $54,70 \%$ sehingga masih $46,30 \%$ yang harus ditangani sehingga tuntas. Namun, bila digunakan standar nasional maka mutu Provinsi Sulawesi Barat telah mencapai $74,98 \%$ sehingga hanya $23,02 \%$ yang perlu ditangani.

Dengan sangat rendahnya nilai pemerataan dan mutu pendidikan program kesetaraan maka bila digunakan standar ideal keberhasilan program kesetaraan Provinsi Sulawesi Barat juga menjadi turun dengan pencapaian $45,74 \%$ sehingga masih $54,26 \%$ yang harus ditangani agar menjadi tuntas. Namun, bila digunakan standar nasional maka keberhasilan program kesetaraan telah tercapai $87,46 \%$ sehingga hanya $12,54 \%$ yang perlu ditingkatkan.

\section{Saran}

Berdasarkan simpulan di atas maka agar program kesetaraan di Provinsi Sulawesi Barat meningkat baik dari segi pemerataan maupun mutu pendidikan tinggi maka beberapa hal perlu diperhatikan oleh pemerintah Provinsi Sulawesi Barat khususnya Dinas Pendidikan Sulawesi Barat, yaitu 1) partisipasi peserta didik program kesetaraan terutama Paket A dan Paket B harus ditingkatkan sehingga APK dapat meningkat, 2) partisipasi peserta didik perempuan di Paket $C$ agar ditingkatkan 3) partisipasi peserta didik agar ditingkatkan sehingga R-PD/KB juga akan meningkat, 3) rekruitmen pendidik harus ditingkatkan baik dari segi jumlah terutama Paket C maupun kualitas ijazah sehingga \%PL meningkat dan mendekati kondisi nasional terutama pendidik Paket A dan Paket B, 4) rekruitmen pendidik sebaiknya berasal dari guru karena sudah memahami bagaimana mengajar, 5) rekruitmen pendidik sebaiknya diikuti dengan pelatihan tentang program kesetaraan sehingga hasilnya maksimal terutama untuk Paket $A$ dan Paket $C, 6$ ) perlu tambahan belajar bagi peserta didik Paket A sehingga lulusan akan meningkat, dan 7) biaya terutama untuk Paket $C$ perlu ditingkatkan karena terlalu kecil ( $\operatorname{Rp} 29.828,00)$ dibandingkan dengan Paket A (Rp473.390,00) dan B (Rp1.024.660,00). Hasil kajian ini dapat dijadikan model untuk diterapkan pada provinsi lainnya.

\section{Pustaka Acuan}

Departemen Pendidikan Nasional. 2003. Undang-Undang Republik Indonesia Nomor 20, Tahun 2003 tentang Sistem Pendidikan Nasional. Jakarta.

Departemen Pendidikan Nasional. 2004. Keputusan Menteri Pendidikan Nasional RI Nomor 129a/U/ 2004 tentang Standar Pelayanan Minimal Bidang Pendidikan. Jakarta.

Departemen Pendidikan Nasional. 2005. Rencana Strategis Departemen Pendidikan Nasional Tahun 2005-2009, Menuju Pembangunan Pendidikan Nasional Jangka Panjang. Jakarta.

Departemen Pendidikan Nasional. 2008. Pembangunan Pendidikan Nasional 2005-2008. Jakarta.

http://bukhari.or.id/home/Stara/index.htm diakses pada tanggal 10 Februari 2010.

http://web.banpnf.or.id/index.php?option =com content\&view=category\&layout=blog\&id $=$ 110\&Itemid $=471$ diakses pada tanggal 12 Februari 2010

Ida Kintamani. 2007. Pendataan Pendidikan. Jakarta: Sekretariat Ditjen Dikdasmen. 
Ida Kintamani. 2009a. Analisis profil Pendidikan Kabupaten Buleleng, Jurnal Pendidikan dan Kebudayaan, Januari 2009, Tahun ke-15, Nomor 1.

Ida Kintamani. 2009b. Pendayagunaan Data Pendidikan. Jakarta: Pusat Statistik Pendidikan.

Pusat Statistik Pendidikan. 2008a. Keberhasilan Program Pembangunan Pendidikan 2006/2007. Jakarta: Depdiknas.

Pusat Statistik Pendidikan. 2008b. Statistik dan Indikator Pendidikan Berwawasan Gender 2006/ 2007. Jakarta: Depdiknas.

Pusat Statisik Pendidikan. 2008c. Pengembangan Model Profil Pendidikan Nonformal. Jakarta: Depdiknas

Surat Edaran Menteri Pendidikan Nasional, Nomor: 107/MPN/MS/2006 Tentang Eligibilitas Program Kesetaraan. 